\title{
TEOR DE GLICOALCALOIDES EM SOLANUM AMERICANUM INFESTADO POR APHIS FABAE SOLANELLA $\left(^{1}\right)$
}

MARCO ANTONIO TEIXEIRA ZULLO (2), JOÃO PAULO FEIJÃO TEIXEIRA, DAYSE SOAVE SPOLADORE, Seçāo de Fitoquimica, ANDRẼ LUIZ LOURENC̣AO (2), Seção de Entomologia Fitotécnica, e CONDORCE'T ARANHA ('2), Seção de Botânica Econômica, Instituto Agronōmico.

\section{RESUMO}

Solanum americanum Miller, uma fonte conhecida de glicosídios de solassodina, foi encontrada infestada por Aphis fabae solanella Theob. Uma vez que esses glicosídios são matérias-primas potenciais para a síntese de outras substâncias esteroídicas, tornou-se de interesse verificar o efeito de infestação sobre o teor destes glicoalcalóides. Plantas fortemente, moderadamente e não infestadas pelo pulgão foram colhidas no campo, determinando-se o teor de glicoalcalóides esteroídicos nos caules, folhas e frutos. Verificou-se que esse teor de glicoalcalóides esteroídicos é dependente do órgão da planta e da fitossanidade do material vegetal. O teor médio de glicoalcalóides em plantas não infestadas é sempre maior que em plantas infestadas, tanto na planta como um todo como em cada órgão examinado. Esses resultados não asseguram que o teor de glicoalcalóides seja responsável pela resistência à infestação, porém que há uma boa correlação entre teor de glicoalcolóides e fitossanidade do material vegetal.

\section{INTRODUÇÃO}

Solanum americanum Miller, conhecida como erva-moura, maria-preta ou maria-pretinha, é uma planta da família Solanaceae

(1) Trabalho apresentado na 35.a Reuniāo Anual da Sociedade Brasileira para o Progresso da Ciência, realizada em Belém (PA) a 6-13 de julho de 1983. Recebico para publicação a 27 de maio de 1983.

(2) Com bolsa de suplementaçăo do CNPq. 
freqiientemente encontrada no País (1) e da qual já se isolaram os glicoalcalóides esteroídicos solassonina, solamargina, $\alpha_{-}$e $\beta$ - solanigrina $(2,9)$, substâncias cuja aglicona é a solassodina, esteróide de importância para a síntese de fármacos contraceptivos (5). Embora a espécie em questão ainda não tenha sido aventada como uma fonte industrial de solassodina, ela apresenta este uso potencial, o que tornou de interesse verificar até que ponto a infestação por pulgões, comum nesta espécie e em outras solanáceas (4), poderia afetar o teor destes glicoalcalóides.

\section{MATERIAL E MÉTODOS}

Plantas de S. americanum Mill., encontradas no Centro Experimental de Campinas, Instituto Agronômico, em agosto de 1982, foram colhidas e separadas em plantas com elevada infestação, plantas com pequena infestação por pulgões e plantas não infestadas. A avaliação da intensidade de infestação foi feita visualmente, sendo apenas qualitativa. O material fresco foi rapidamente lavado com água, limpo dos insetos remanescentes e seco em estufa com ventilação a $50^{\circ} \mathrm{C}$ até peso constante.

A parte aérea das plantas foi separada em caule, folhas e frutos, e cada porção foi moída e extraída por 48 horas com $20 \mathrm{ml}$ de ácido acético a $5 \%$ aquoso. Após filtração do extrato, seu volume foi completado a $25 \mathrm{ml}$, tomando-se uma alíquota de $1 \mathrm{ml}$ para a determinação do teor de glicoalcalóides, segundo o método colorimétrico de WANG et alii (11). As determinações foram feitas em duplicata para cada amostra. A curva-padrão foi construída a partir de uma mistura de glicoalcalóides isolada de frutos verdes de $\mathbf{S}$. americanum.

Os pulgões foram identificados como sendo Aphis fabae solanella Theob. (Homoptera: Aphididae).

\section{RESULTADOS E DISCUSSÃo}

Pela Figura 1 - teor de glicoalcalóides encontrado segundo os órgãos e intensidade de infestação - observa-se que em qualquer dos órgãos das plantas infestadas, ele é menor que nos órgãos das plantas não infestadas: enquanto nas folhas o teor se mostrou comparávef para plantas com elevada e pequena intensidade de infestação, no caule mostrou-se muito pequeno nas plantas com baixa intensidade de infestação, cerca de $20 \%$ do observado nas outras plantas infestadas. Nos frutos, o teor de glicoalcalóides apresentou-se inversamente proporcional à intensidade de infestação da planta. A análise de variância dos dados obtidos mostrou que o teor de glicoalcalóides é dependente da intensidade de infestação, do órgão da planta e da interação entre ambos. 


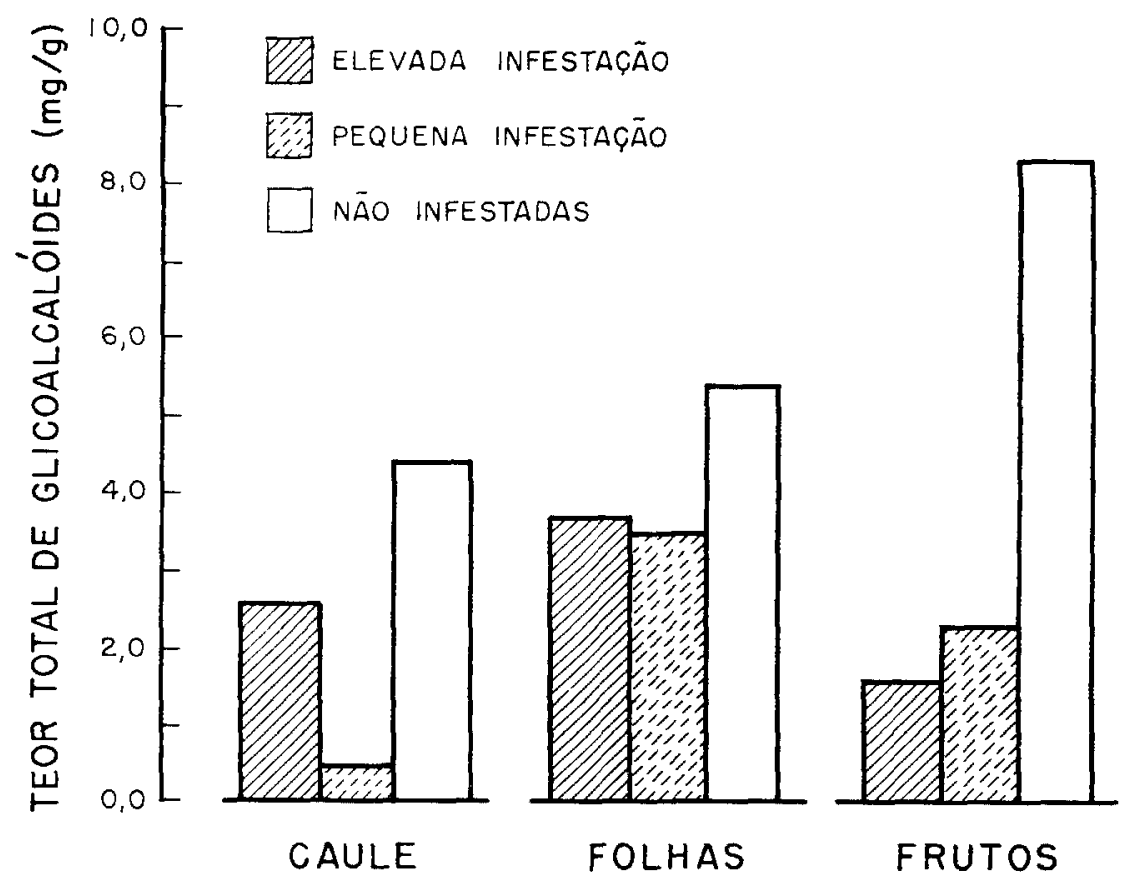

FIGURA 1 - Teor de glicoalcalóides encontrado nos diferentes órgāos de Solanum americanum, de acordo com a intensidade de infestação por Aphis fabae

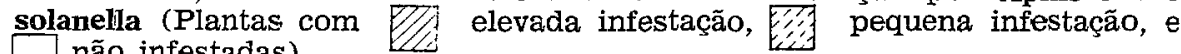
não infestadas) 
Os dados obtidos não permitem, todavia, saber se a diminuição dos teores de glicoalcalóides é a responsâvel pela infestação ou se a infestação é a responsável pela diminuição desses teores. Sabendo-se que tais glicoalcalóides são dotados de ação inseticida (6), torna-se provável que plantas com elevado teor de glicoalcalóides sejam resistentes à infestação por estes pulgões. Deve-se notar ainda que, mesmo estando o teor de glicoalcalóides associado à fitossanidade de $\mathbf{S}$. americanum, estas substâncias podem não ser as responsáveis pela aparente resistência verificada, mas apenas os indicadores da concentração de substâncias biossinteticamente correlatas e não investigadas até o momento nesta espécie, a exemplo dos whitanolídios encontrados em solanáceas dos gêneros Acnistus (8), Physalis (7) e Whitania (3) ou das fitoalexinas sesquiterpênicas encontradas em outras espécies do gênero Solanum (10), e que são sintetizadas em resposta a infecções.

\section{SUMMARY}

\section{GLYCOALKALOID CONTENT IN SOLANUM AMERICANUM INFESTED BY APHIS FABAE SOLANELLA}

Solanum americanum Mill, a known source of solasodina glycosides, was found to be infested by the aphids Aphis fabae solanella Theob. Since these glycosides are potential raw materials for the synthesis of steroidal drugs, it is important to know the effect of infertation on the yield of solasodine glycosides. Plants heavily, moderately and uninfested by the aphids were collected in the field, and the glycoalkaloid content of the stems, leaves, and fruits were determined. It was found that the glycoalkaloid content is dependent on the different parts of the plant and phytosanity of the plant material. The average yield of glycoalkaloids in uninfested plants was always higher than in infested plants, both in the whole plant or in each part of the plant examined. These results cannot assure that the glycoalkaloid content is responsible for the resistance, but that there is a close relationship between glycoalkaloid content and phytosanity of the plant material.

\section{AGRADECIMENTOS}

A Sônia M. F. Campos e Silvana M. Silva, pelo suporte técnico.

\section{REFERENCIAS BIBLIOGRAFICAS}

1. ARANHA, C.; BACCHI, O.; LEITÃO Fo., H. F. Plantas invasoras de cultura no Estado de São Paulo. São Paulo, Ministério da Agricultura, Agiplan. Banco Interamericano de Desenvolvimento, 1975, v.2, p.552-554.

2. BRIGGS, L. H.; CAMBIE, R. C.; HOARE, J. I. Solanum alkaloids. Part XV. The constituents of some Solanum species and a reassessment of solasodamine and solauricidine. Journal of the Chemical Society:4645-4649, 1961.

3. CORDELI, G. A. \& FARNSWORTH, N. R. Experimental antitumor agents from plants, 1974-1976. Lloydia, 40(1):1-44, 1977 
4. COSTA, C. I.; EASTOP, V. S.; COSTA, A. S. A list of the aphid species (Homoptera: Aphidoidea) collected in São Paulo, Brazil. Revista Peruana de Entomologia, 15(1):131-134, 1972.

5. HARRISON, D. M. Solanum and Veratrum steroidal alkaloids. In: SAXTON J. E., ed. Specialist Periodical Reports, the Alkaloids. London, The Chemical Society, 1976 . p.285-295.

6. ISMAN, M. B. \& DUFFEY, S. S. Toxicity of tomato phenolic compounds to the fruitworm, Heliothis zea. Entomologia Experimentalis et Applicata. 31:370-376, 1082 .

7. KIRSON, I.; ABRAHAM, A.; SETHI, P. D.; SUBRAMANIAN, S. S.; GLOTTER E. $4 \beta$-Hydroxywhitanolide $E$, a new natural steroid with a $17 \propto$-oriented side chain. Phytochemistry, 15:340-342, 1976.

8. ROSAZZA, J. P. Microbial transformations of natural antitumor agents Lloydia, 41(4):297-311, 1978.

9. SCHREIBER, K. Steroid alkaloids: the Solanum group. In: MANSKE, $R$. H. F., ed. The Alkaloids. Chemistry and Physiology. New York, Academic Press, 1968. v.10, p.1-192.

10. STOESSL, G. A.; WARD, E. W. B.; STOTHERS, J. B. Biosynthetic rela tionships of sesquiterpenoidal stress compounds from the Solanaceae. In. HEDIN, P. A.. ed. Host Plant Resistance to Pests. Washington, American Chemical Society, 1977. p.61-77.

11. WANG, S. L., BEDFORD, C. L., THOMPSON, N. R. Determination of glycoalkaloids in potatoes (S. tuberosum) with a bisolvent extraction method. American Potato Journal, 49:302-308, 1972. 